\title{
Examination on Trainning and Development
}

\author{
P. Tamil Selvam, Ramamoorthy, R.M. Ninushaa
}

\begin{abstract}
The Data collected for the assessment were head and discretionary data, the key data amassed from the specialists of the affiliation and the ornamentation data accumulated from the books, intrigue supports, and web for the assessment. The kind of research got for the endeavor was illustrative in nature. Test size of 110 virtuosos, test people is 195, the kind of concentrate used is maintained, open-completed, close - completed charts, moving choice, and dichotomous structures.

Catchphrases: Training and Development, Employee limit.
\end{abstract}

\section{INTRODUCTION}

Getting oversaw is a development of activities activated see issues or various issues in the work place, and to pick getting created is a fitting response. The necessities assessment is persistently the verbalized improvement taken to cause a change. This is in a general sense in light of the path by which that a necessities assessment unequivocally plots the opening between the current and the perfect individual and veritable shows [1-4].

Building need appraisal is a focal need to the structure of influencing structure. The explanation behind structure need assessment is to pick if there is an opening between what is required for goliath execution and the drag onlooker to execution [5].

Overseeing need evaluation is made to pick if resources required are open or not. It structures the cash related most remote degrees of the highest point of the line, zones where getting animated is required, what's more joins the occasions where organizing might be required [6,7].

\section{LITERATURE REVIEW}

O.Jeff Harries, Jr. Observes and states that

"Training of any kind should have as its objective the redirection or improvement of behaviors so that the performance of the trainees becomes more useful and productive for him shelf and for the organization of which he is a part normally concentrates on improvements of their operative skills, interpersonal skills, or a combination of these." $[8,9]$.

Edwin B Flippo states that

"Training is the act of increasing the knowledge and skill of an employee for doing a particular job," [10,11].

Penn State Harries bur defines

Revised Manuscript Received on July 22, 2019.

P. Tamil Selvam, Department of Management Studies, Bharath Institute of Higher Education and Research, Chennai, India

Ramamoorthy, Department of Management Studies, Bharath Institute of Higher Education and Research, Chennai, India

R.M. Ninushaa, Department of Management Studies, Bharath Institute of Higher Education and Research, Chennai, India
"The training and development profession focuses on analyzing and improving employee learning and performance. It encompasses such activities as performance analysis, training, career development, organization development, and program evaluation.” $[12,13]$

\section{OBJECTIVES OF THE STUDY}

Primary objective

- To study the training need at Shree Ambika sugars ltd.

Secondary objective

- To find out the whether the organization is willing to provide training program at Shree ambika sugar mills ltd.

- To find out Importance, Frequency and Complexity of the jobs.

- To find out the level of knowledge, skill and ability of the employees.

- To give suggestion to improve more training to the employees by the organization.

\section{RESULTS AND DISCUSSION}

It is found from the data that $78.18 \%$ of the employees are male in the company. Remaining $21.82 \%$ of the employees are female in the company

It is found from the data that $33.64 \%$ of the employees are $41-50$ years age group of people in the company, $26.36 \%$ of the employees are $31-40$ years age group of people in the company, $23.64 \%$ of the employees are 20 - 30 years age group of people in the company, Remaining $16.36 \%$ of the employees are above-50 years gentle man working in the company.

From the above table shows it is clear that out of 110 respondents, collection of the data is given $79.09 \%$ of the employees are married in the company. Remaining $20.91 \%$ of the employees are single in the company.

It is found from the data that $32.73 \%$ of the employees are below-(+2) of people in the company, $25.45 \%$ of the employees are diploma people in the company, $21.82 \%$ of the employees are Under graduation people in the company, $11.82 \%$ of the employees are other people in the company, Remaining $8.18 \%$ of the employees are post graduation peoples working in the company.

It is found from the data that $38.18 \%$ of the employees are getting 5000-8000 rupees salary in the company, $28.18 \%$ of the employees are getting 8001-12000 rupees salary in the company, $20.91 \%$ of the employees are getting 12001-15000 rupees salary in the company, 
Remaining $12.73 \%$ of the employees are getting above-15000 rupees getting salary in the company.

It is found from the data that $42.73 \%$ of the employees are below-5 years experience in the company, $29.09 \%$ of the employees are 5-8 years experience in the company, $20.91 \%$ of the employees are 9-12 years experience in the company, Remaining $7.27 \%$ of the employees are above-12 years experience in the company.

It is found from the data that 81.82 of the respondents belong to yes. 18.18 of the respondent belong to no.

It is found from the data that $10.91 \%$ of the respondents belong to below-3days, 16.36 of the respondent belong to one week , $9.09 \%$ of the respondent belong to two week, and $45.45 \%$ of the respondent belong to one-month, $18.18 \%$ of the respondent below above-one month

It is found from the data that 72.73 of the respondents belong to on the job training, 18.18 of the respondent belong to off the job training, 9.09 of the respondent belong to both.

\section{SUGGESTIONS}

Training should be conducted in the organization periodically in order to assess the training requirements of the employees.

The performance appraisal system should be more effective.

A well organized and specialized training program should be conducted for the employees working in the Boiler Operation under Engineering department to upgrade their Knowledge, Skills and Abilities.

A training calendar is necessary for the organization to train the employees periodically in appropriate time.

\section{CONCLUSION}

The term "Training" refers to the difference between the actual level of Knowledge, Skill and Ability and those of the required level.

The basic training required for a trade, occupation or, Profession, observers of the labor market recognize today the need to continue training programs to maintain, upgrade and update the employees' knowledge, skills and ability.

Effective training has specific goals of improving one's capacity, capability and performance.

From this study it is concluded that, although overall training needs of the employees is above the average level, the employees in the Boiler Operation are lacking in expertise knowledge, skills and ability to perform their task.

And this study concluded that Boiler Operation is the most Important task in the organization.

Also the employees are keen to undergo a specific training program to increase their knowledge, skill and ability.

\section{REFERENCES}

[1] BharthVajan R., Ramachandran S.,Psychographic dimensions of training,2016,International Journal of Pharmacy and Technology,V-8,I-4,P-23727-23729

[2] Balakrishnan P., Bharthvajan R.,A study on human resource planning in hospitals in Chennai City,2014,International Journal of Applied Engineering Research,V-9,I-22,P-7503-7507
[3] Priyadarsini P., Bharthvajan R.,Role of emotional intelligence training programme in reducing the stress of the nurses,2014,International Journal of Applied Engineering Research,V-9,I-22,P-7411-7421

[4] Kerinab Beenu G., Bharthvajan R.,Empirical analysis on the cosmetic buying behavior of young women in South India,2014,International Journal of Applied Engineering Research,V-9,I-22,P-7361-7366

[5] Balakrishnan P., Bharthvajan R.,Whistling in the wind,2014,International Journal of Applied Engineering Research,V-9,I-22,P-7586-7593

[6] Krishnan B., Peter M.,Health hazards of Indian Bpo employee-an alarming issue,2014,International Journal of Applied Engineering Research,V-9,I-22,P-7336-7341

[7] Kerinab Beenu G.H., Peter M.,Role of insurance in economic development,2014,International Journal of Applied Engineering Research,V-9,I-22,P-7532-7539

[8] Balakrishnan P., Peter M., Priyadarsini P.,Efficiency of safety measures for wellbeing of employees in manufacturing industry,2014,International Journal of Applied Engineering Research,V-9,I-22,P-7376-7382

[9] Anbarasi M., Praveen Kumar S.,Online sales promotions of herbal products and its effectiveness towards tanisha.com,2019,Indian Journal of Public Health Research and Development,V-10,I-1,P-195-200

[10] Anbarasi M., Praveen Kumar S.,Various online marketing and promotions strategies to improve the validation towards the organic products in the pharmaceutical sectors,2019,Indian Journal of Public Health Research and Development,V-10,I-1,P-263-269

[11] Loganathan R., Praveen Kumar S.,Grievance handling a key factor for solving issues of employees in an organization,2014,International Journal of Applied Engineering Research,V-9,I-22,P-7483-7491

[12] Loganathan R., Praveen Kumar S.,Study on preference of private label brands in super and Hypermarkets,2014,International Journal of Applied Engineering Research,V-9,I-22,P-7327-7335

[13] Smitha M., Praveen Kumar S.,Understanding stress and its managementamong the nurses in Chennai city,2014,International Journal of Applied Engineering Research,V-9,I-22,P-7560-7565

[14] Kerinab Beenu G.H., Praveen Kumar S.,A study on the investment behavior of Chennai investors in mutual fund schemes,2014,International Journal of Applied Engineering Research,V-9,I-22,P-7520-7525

\section{AUTHORS PROFILE}

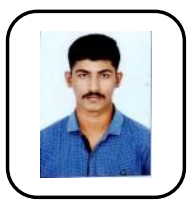

P. Tamil Selvam, Student, Department of Management Studies, Bharath Institute of Higher Education and Research, Chennai, India

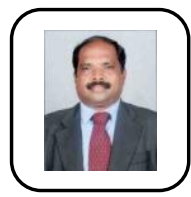

Ramamoorthy, Associate Professor, Department of Management Studies, Bharath Institute of Higher Education and Research, Chennai, India

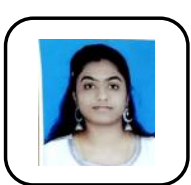

R.M. Ninushaa, Student, Department of Management Studies, Bharath Institute of Higher Education and Research, Chennai, India 